\title{
Botulinum toxin promoted healing and relieved symptoms of chronic anal fissure
}

\author{
Maria $G$, Cassetta $E$, Gui D, et al. A comparison of botulinum toxin and saline for the treatment of chronic \\ anal fissure. $N$ Engl $\mathcal{F}$ Med 1998 fan 22;338:217-20.
}

\section{Question}

In patients with chronic anal fissures, is local infiltration of botulinum toxin effective for healing fissures and relieving symptoms?

Design

2 month randomised, double blind, placebo controlled trial.

\section{Setting}

Clinical centre in Rome, Italy.

\section{Patients}

30 patients (mean age $44 \mathrm{y}, 67 \%$ men) with chronic, idiopathic anal fissures. Exclusion criteria were acute fissures, anal fissures with various causes (haemorrhoids, fistula in ano, or inflammatory bowel diseases), or previous anal surgery. Follow up was complete.

\section{Intervention}

Patients were allocated to $0.4 \mathrm{ml}$ in 2 injections of either botulinum toxin A (Botox, Allergan, Irvine, CA, USA), 20 $\mathrm{U}(\mathrm{n}=15)$, or saline placebo $(\mathrm{n}=15)$, injected with a 27 gauge needle. Patients were advised to eat food with a high fibre content and received a prescription for laxatives.

\section{Main outcome measures}

Anal fissure healing and symptomatic relief (persistence of anal fissure without symptoms). Patients were assessed at 1 and 2 months.

\section{Main results}

At 1 and 2 months, more patients allocated to botulinum toxin than to placebo had healed fissures ( $p=0.05$ at 1 month and $p=0.003$ at 2 months) and symptomatic relief $(p=0.003$ for both 1 and 2 months follow up) (table). 4 patients who still had fissures were retreated with botulinum toxin, $25 \mathrm{U}$, and all achieved complete healing within 2 months of rescue treatment. No relapses occurred among patients in the botulinum toxin group during a mean follow up of 16 months. 10 patients in the control group received botulinum toxin, $20 \mathrm{U}$ each, and 3 patients underwent sphincterotomy at 2 months. No relapses occurred after rescue treatment in the control group during a mean follow up of 18 months.

\section{Conclusion}

Botulinum toxin promoted healing and relieved symptoms of chronic anal fissure.

Source of funding: in part, Consiglio Nazionale delle Ricerche.

For correspondence: $\operatorname{Dr}$ A Albanese, Istituto di Neurologia, Università Cattolica, Largo Argostino Gemelli 8, I-00168 Rome, Italy. Fax +39-635-501909.

Botulinum toxin $v$ placebo for chronic anal fissure*

\begin{tabular}{lllll}
\hline Outcomes & $\begin{array}{l}\text { Botulinum } \\
\text { toxin }\end{array}$ & Placebo & RBI (95\% CI) & NNT (CI) \\
\hline $\begin{array}{c}\text { Healed fissure at } \\
\quad 1 \text { mo }\end{array}$ & $53 \%$ & $13 \%$ & $300 \%(20$ to 1415$)$ & $3(2$ to 17$)$ \\
$\begin{array}{c}\text { Healed fissure at } \\
\quad 2 \text { mo }\end{array}$ & $73 \%$ & $13 \%$ & $450 \%(79$ to 1913$)$ & $2(1$ to 4$)$ \\
$\begin{array}{c}\text { Symptomatic } \\
\text { relief at } 1 \text { mo }\end{array}$ & $87 \%$ & $27 \%$ & $225 \%(56$ to 708$)$ & $2(1$ to 4$)$ \\
$\begin{array}{c}\text { Symptomatic } \\
\text { relief at } 2 \text { mo }\end{array}$ & $87 \%$ & $27 \%$ & $225 \%(56$ to 708$)$ & $2(1$ to 4$)$ \\
\hline
\end{tabular}

${ }^{\star} \mathrm{RBI}=$ the proportional increase in rates of good events between the botulinum toxin and placebo groups; NNT=the number of patients who must receive botulinum toxin to achieve 1 additional good outcome.

\section{Commentary}

Fissure is common, lying on the inside of the distal anal canal, usually posteriorly, but it is easily missed clinically unless traction is exerted on the rim of the anal canal. Local trauma by constipated stools leads to a tear; spasm and the resulting poor perfusion lead to an ischaemic ulcer which fails to heal. ${ }^{1}$

Non-operative treatments such as laxatives and local anaesthetics try to break the pain/constipation cycle. In failures, surgical sphincterotomy reduces resting anal pressure, improves local blood flow and successfully heals the fissure, but at the price of (usually minor) incontinence in a few.

Resting anal pressure can also be reduced either by local application of a nitric oxide donor such as glyceryl trinitrate (GTN) or by injection of botulinum toxin A. Maria et al report a small randomised trial in 30 patients of $20 \mathrm{U}$ botulinum toxin A versus saline $(0.4 \mathrm{ml}$ of each) injected into the internal anal sphincter in outpa- tients with neither sedation nor anaesthetic. The treated patients were on average nine years younger and eight were women, compared with only two female controls. By two months, $73 \%$ of treated patients had healed compared with $13 \%$ of controls $(p=0.003)$. After treatment of failures only six patients underwent surgery, all initially controls. By an average of 16 months follow up there had been no recurrences.

The alternative and probably equally effective new local therapy of $0.2 \%$ GTN cream needs to be diluted in soft paraffin wax in local pharmacies from the currently commercially available $2 \%$ cream. $^{2}$ Headache can be a problem. Bethanechol and diltiazem, alone or combined, are even newer options which work through different pathways without the side effects seen with GTN. ${ }^{3}$

Before surgeons are asked to hang up their scalpels for good, gastroenterologists and general practitioners should be wary of future recurrences and know that other conditions, familiar to surgeons, mimic or even open into fissures. Furthermore, patient satisfaction with surgical sphincterotomy generally remains high.

R K S PHILLIPS Department of Surgery, St Mark's Hospital, Northwick Park, Watford Road, Harrow, Middlesex HA1 3fU, UK

1 Schouten WR, Briel JW, Auwerda JJ. Relationship between anal pressure and anodermal blood flow: vascular pathogenesis of anal fissures. Dis Colon Rectum 1994;37:664-9.

2 Lund JN, Scholefield JH. A randomised, prospective, double blind, placebo-controlled trial of glyceryl trinitrate ointment in treatment trial of glyceryl trinitrate ointment in treatment

3 Carapeti EA, Kamm MA, Phillips RKS. Diltiazem lowers resting anal sphincter pressure - a potential low side effect alternative to glyceryl trinitrate for fissures. Gut 1998; 42(suppl 1):A97. 